\title{
Designing a university seminar to professionalize prospective teachers for digitization in chemistry education
}

\author{
${ }^{1}$ TU Dortmund University, Chemistry and Chemical Biology/Chemical Education, Otto-Hahn-Str. 6, 44227 Dortmund, Cer- \\ many, E-mail: franziska.zimmermann@tu-dortmund.de, insa.melle@tu-dortmund.de
}

\begin{abstract}
:
The legal obligation to implement digital tools in teaching and learning at all German schools poses a challenge to all teachers since the majority of teachers feel that they are not well enough prepared to meet the requirements. It is therefore of great importance to professionalize both teaching staff and prospective teachers for implementing digital tools effectively and appropriately. Therefore, within this project we develop and evaluate an innovative university seminar that aims at the professionalization of prospective teachers for digitization in chemistry education by providing the requisite skills. The study is an intervention study that tests the interventions' effects by using repeated measures. In reference to the TPACK (technological pedagogical content knowledge) model, we explore the potential implications of the seminar to the future teachers' teaching practices on the levels of self-efficacy, lesson planning and practical implementation. Consequently, this study does not only reflect one important area of teaching practice, but consists of a comprehensive analysis of TPACK knowledge. Additionally, the study also aims to determine potential implications for other teaching programs. The first results of the pilot study show that the seminar participants assess the seminar as very attractive. Moreover, the seminar participation led to a significant positive change regarding the prospective teachers' attitudes towards the implementation of digital tools in chemistry lessons as well as their TPACK self-efficacy perceptions.
\end{abstract}

Keywords: Digital tools, digitization, professionalization of teachers, TPACK

DOI: 10.1515/cti-2018-0025

\section{Introduction}

Since the publication of the strategic concept "Education in the Digital World" in Germany in 2016, learning with and about digital media and digital tools has become mandatory at all German schools (KMK, 2016). While education policy makers have recognized the great potential of innovative information and communication technologies regarding teaching and learning, German schools are, especially in times of inclusion, facing the challenge of implementing the law and adapting to the increasingly digitalized society (Drossel \& Eickelmann, 2017; Meyer, Rose, \& Gordon, 2014). Hence, the qualification of teachers sets the essential basis to ensure this transformation process (Cetin-Dindar, Boz, Sonmez, \& Celep, 2018; Mahler \& Arnold, 2017; Schmid, Goertz, \& Behrens, 2017). Consequently, this project aims to develop and evaluate a university seminar that prepares prospective chemistry teachers for implementing digital tools in teaching as well as learning effectively and appropriately. In order to understand teachers' required knowledge for technology integration and investigate the seminar participants' development, the technological pedagogical content knowledge (TPACK) serves as a theoretical framework of this research (Mishra \& Koehler, 2006). By determining the seminar participants' development in TPACK knowledge on the stages of self-efficacy, lesson planning and practical performance, this study shall finally provide implications for suitable teaching programs. Consequently, this evaluation comprises a comprehensive assessment of pre-service teachers' TPACK competencies since it analyzes a wide range of correlating effects of teacher training programs. This paper provides first results of the pilot study. 


\section{Theoretical background}

\section{Digital learning}

With the advent of digitalization in the world we live and work in, there is no doubt that the demands placed on education have markedly changed (Drossel \& Eickelmann, 2017). Therefore, this digital change encompassing all areas of life and work will also mean that more "digital key competences" will have to be acquired along the entire educational pathway and in all subjects. These "digital key competences" will thus become a new fourth cultural technique, alongside writing, reading and arithmetic (Landesregierung NRW, 2016). However, digital media are not only crucial to be prepared for the challenges of today's digital world, they can also contribute to increasing the learning success. Thus, recent findings demonstrate that the use of digital media in teaching and learning has an overall positive effect on secondary education (Hattie, 2008; Hillmayr, Reinhold, Ziernwald, \& Reiss, 2017).

Nevertheless, only about one third of teachers see the potential of digital media in teaching and learning, consequently, two thirds do not believe that the use of digital media can increase students' learning success (MPFS Medienpädagogischer Forschungsverbund Südwest, 2017). This in turn is reflected in the frequency of use since digital media are only used to a minor degree at schools and almost exclusively as a presentation medium (Bang \& Luft, 2013; Gerick \& Eickelmann, 2017). In addition, recent school performance studies such as the International Computer and Information Literacy Study (ICILS) show that German students have a rather weak level of computer- and information-related skills in the international comparison (European Commission, 2014). Hence, less than a quarter of eighth-graders are able to self-reliantly search for and process information with a computer, even though almost all of them own a smartphone or a comparable mobile device (MPFS Medienpädagogischer Forschungsverbund Südwest, 2017). Given this current situation at German schools, it can therefore be concluded that, at present, German schools fail to recognize the educational potential of digital tools (Schmid et al., 2017). However, the mere legal requirement to create a digital learning culture in schools is not sufficient. The obvious lacking implementation of digital learning may also lie in the missing framework conditions that are necessary for the successful implementation of the requirements (Becker \& Nerdel, 2017; Otterborn, Schönborn, \& Hultén, 2018). Thereby, decisive prerequisites for successful learning with digital tools are at the technological level, the content-related level and the personnel level. These levels again, are closely interlinked and interdependent (Becker \& Nerdel, 2017).

Yet, it appears that the digitization of education either stands or falls with the teacher (Drossel \& Eickelmann, 2017; Schmid et al., 2017). However, teachers state that they do not feel qualified and, above all, overstrained concerning their abilities to implement digital tools in teaching and learning. Consequently, there are high training needs of teaching staff and prospective teachers (Bos et al., 2016; Chai, Koh, \& Tsai, 2013; Drossel \& Eickelmann, 2017). Recent studies confirm these high training needs and point out that only $15 \%$ of teachers are experienced in the use of digital forms of learning. In addition, this need for further training is even confirmed by students' statements. It is also revealed that digitally experienced teachers rate digital learning more positively than digitally inexperienced teachers (Schmid et al., 2017). These findings suggest that teachers will only recognize the potential of digital tools for teaching and learning if they actually have the appropriate skills to implement them.

Against this background, it becomes evident that there is an urgent need for action regarding the professionalization of teachers for digitization. This goal can only be achieved by systematically building up or broadening media-didactic competences in continuing education and training programs (Bastian \& Riplinger, 2016; Becker \& Nerdel, 2017; Instefjord, 2015; Mahler \& Arnold, 2017). Therefore, it is also of great importance to identify and formulate the exact competences that teachers have to develop in the context of the required digitization in schools.

\section{Teacher expertise}

To describe the necessary professional knowledge of teachers for the use of technologies in school teaching, there are various frameworks for teacher knowledge. The model referred to in this project is based on Shulman's pedagogical content knowledge, a model to describe teacher expertise (Shulman, 1986).

On the one hand, the professional knowledge of teachers consists of content knowledge (CK). This is knowledge about facts, concepts or structures of a specific subject. On the other hand, the professional knowledge comprises pedagogical knowledge (PK), which describes the knowledge for teaching and learning. Their intersection is the pedagogical content knowledge (PCK), which refers to the didactic knowledge of the subject that is necessary for imparting subject-related knowledge (Fischer, Borowski, \& Tepner, 2012; Shulman, 1986). 
When describing the competences for digitization, Shulman's model is extended to include technological and technology knowledge (TK) as Figure 1 shows. This represents the knowledge about technologies and their applications. At the same time, this results in further areas of knowledge with regard to technology. Firstly, this includes technological pedagogical knowledge (TPK), which is the knowledge for the selection and use of technologies to promote learning processes. One other additional field of knowledge is technological content knowledge (TCK), which encompasses knowledge about technologies for subject-specific content, without any reference to school teaching. Technological pedagogical content knowledge (TPACK) is the intersection of all fields of knowledge. It is the basis of effective teaching with technologies, representing the knowledge for the selection and use of technologies for promoting learning processes to teach subject-related content. These different forms of knowledge areas are, however, additionally linked to the respective context, i.e. the situational conditions, such as the interior design, the classroom climate or the school concept (Mishra \& Koehler, 2006.

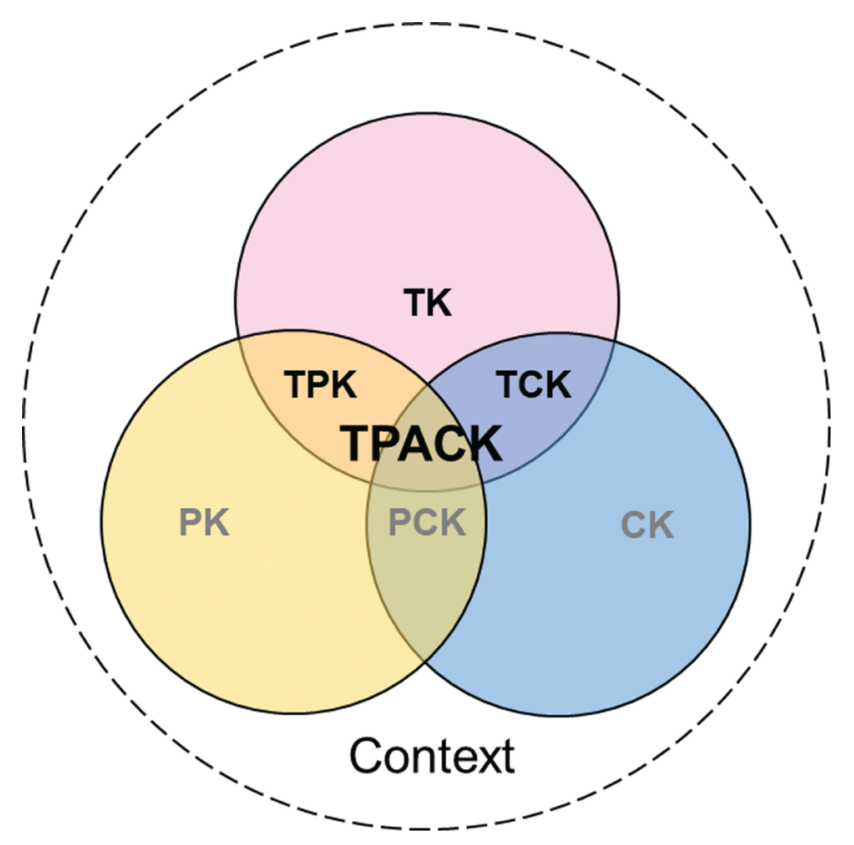

Figure 1: The TPACK model (cf. Mishra \& Koehler, 2006).

In summary, it is striking that this TPACK model can not only be used to describe the necessary competences of teachers. Above all, the addition of further forms of knowledge also demonstrates how complex and demanding the requirements placed on teachers have become with the increased use of technologies and the raising digitization (Cetin-Dindar et al., 2018; Mahler \& Arnold, 2017; Mishra \& Koehler, 2006).

\section{Effects of training programs}

The growing requirements and the current situation at German schools show that in order to successfully use digital tools in teaching, it is crucial to comprehensively strengthen teachers' digital skills through appropriate training programs (Becker \& Nerdel, 2017; Drossel \& Eickelmann, 2017; Mahler \& Arnold, 2017; Schmid et al., 2017). In addition to imparting skills, training programs can achieve further positive effects as Figure 2 illustrates.

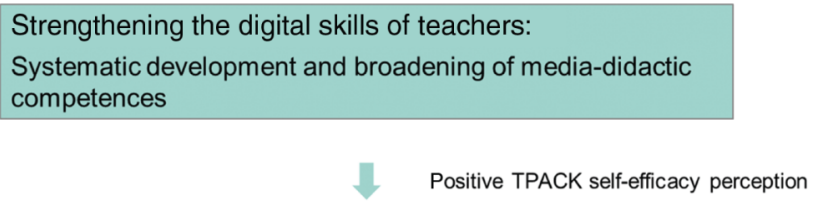

Positive intention to use 
Figure 2: Effects of training programs (cf. Bastian \& Riplinger, 2016; Becker \& Nerdel, 2017; Davis, Bagozzi, \& Warshaw, 1989; Mahler \& Arnold, 2017; Sánchez-Prieto, Olmos-Migueláñez, \& García-Peñalvo, 2016; Schmid et al., 2017).

By strengthening teachers' digital skills, the development of a positive self-efficacy perception is promoted at the same time (Mahler \& Arnold, 2017; Paulick, Großschedl, Harms, \& Möller, 2016). Positive self-efficacy perceptions, in turn, can have a positive influence on teachers' attitudes and are also an important condition for the success of digital learning. Thus, qualification programs cannot only strengthen competences, but can also help teachers to gain more acceptance for the continuing digitalization of teaching and can thereby positively influence their convictions regarding digital tools (Becker \& Nerdel, 2017; Instefjord, 2015; Schmid et al., 2017). Whether digital tools are actually effectively implemented in the classroom, particularly depends on the attitude towards digital media since a positive attitude ultimately triggers a positive intention to use technologies for teaching (Bastian \& Riplinger, 2016; Davis et al., 1989; Instefjord, 2015; Sánchez-Prieto et al., 2016). Nonetheless, TPACK performance assessments analyzing the entirety of the presumed effects of training programs as depicted in Figure 2 are still quite new research areas.

\section{Research questions and design}

Based on this theoretical background, this project focuses on the personnel level to meet the legal requirements. Consequently, we have developed a seminar to strengthen the digital competences of future chemistry teachers. The aim, however, is not only to develop the seminar but also to evaluate it in order to ultimately determine implications for other teaching programs. Since all students enrolled in a teaching-oriented master's degree program at our university also have to participate in an internship semester, we can also evaluate the implementation of the seminar contents in school lessons.

In order to analyze the impact of the seminar, we apply the training evaluation method by Kirkpatrick (1979), which is a method for evaluating the educational success of any training program. This method contains the following four different levels: (1) reaction, (2) learning, (3) behavior and (4) results.

In the first evaluation step it is assessed how well the trainees like a particular training program. The second evaluation step determines the amount of learning that takes place. Since there is a big difference between knowing principles and techniques and actually using them in practice, it is also important to assess what exactly is effectively applied in practice. Lastly, the forth evaluation step measures the actual impact of the training program and thus, if the desired results are met. Following these evaluation steps, we evaluate the impact of our seminar on the levels of (1) attractiveness, (2) cognitive changes, (3) implementation at school and (4) effects on learners (cf. Nienaber \& Melle, 2018; Schlüter \& Melle, 2018). Based on these adapted evaluation steps, we aim to answer the following research questions:

Attractiveness:

Q1: How do the future teachers assess the seminar?

Cognitive changes:

Q2: Does the seminar have an impact on the prospective teachers' ...

... attitudes towards the implementation of digital tools in chemistry lessons

... self-efficacy perceptions?

Q3: Do the future teachers improve their skills in integrating digital tools in their lesson plans?

Implementation at school:

Q4: Are the future teachers able to adequately implement the seminar contents during their internship semester?

Effects on learners:

Q5: Which effects do the seminar participants' lessons have on the students at school?

To answer these research questions, we developed a seminar with the title "Teaching Methods and Multimedia for Digitization in Chemistry Education". The sample group of this study comprises all master students of chemistry education at the TU Dortmund. As the schedule in Figure 3 demonstrates, the pilot study started in the summer semester in 2018. 


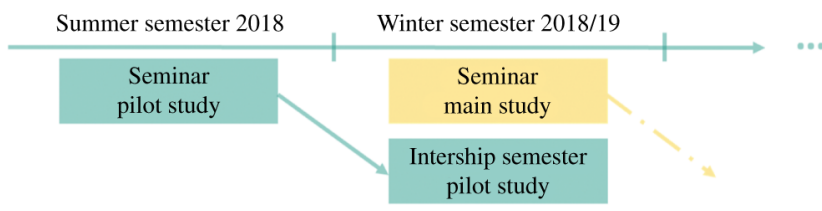

Figure 3: Intervention schedule.

In the first seminar session the seminar participants' attitude towards teaching with digital tools, their TPACK self-efficacy as well as their prior experience in dealing with digital media are determined (cf. Figure 4). Likewise, it is surveyed to what extent the students are already able to integrate digital tools in lesson plans. Then, the intervention, which consists of twelve seminar sessions, takes place. After each thematic block, a mid-test is conducted with the aid of which we measure the seminar's quality of each thematic block. In the last seminar session, we assess the students' ability to integrate digital tools in their lesson plans once more in order to compare their pre and post results. Moreover, the impact of the seminar on the students' attitudes and self-efficacy perception is evaluated through a pre-post comparison. Furthermore, the students assess the attractiveness of the working phases, the methodological design and the given presentations by the lecturer. During the following semester, the implementation of the seminar contents will be examined during the seminar participants' internship semester in schools. In addition to videotaping the implemented lessons, the effects of the seminar participants' lessons on the learners will be determined.

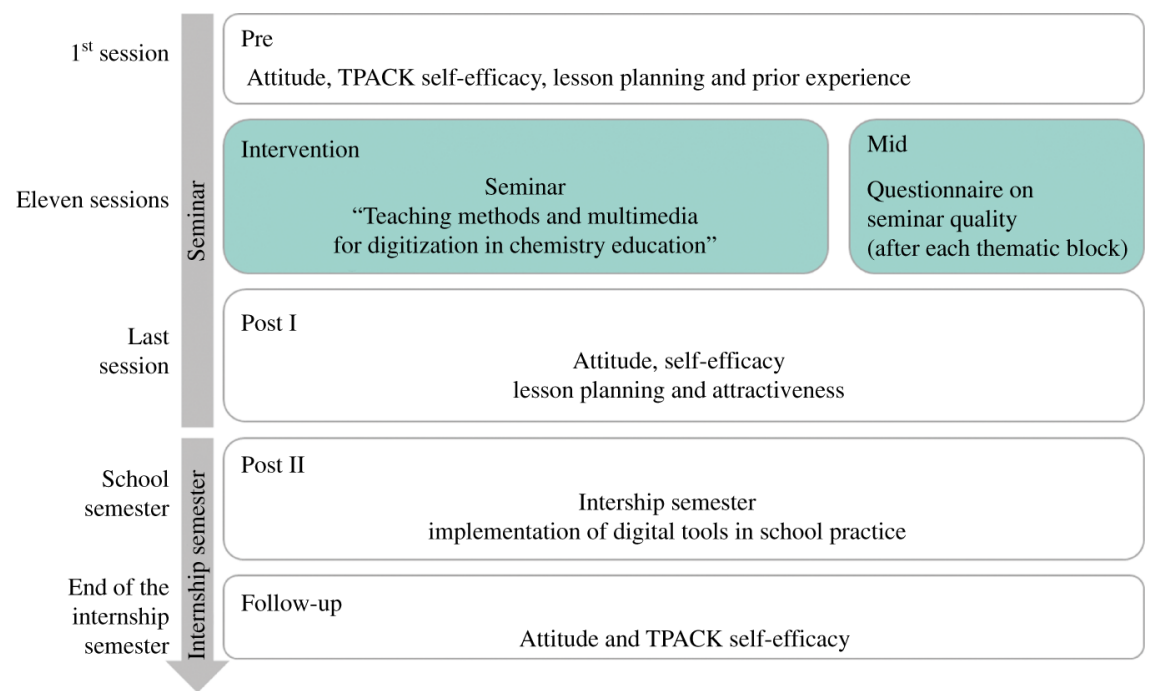

Figure 4: Research design.

Finally, the long-term impact of the seminar on the future teachers' attitude and self-efficacy will be assessed at the end of the internship semester.

To measure the intervention's success, we use various test and evaluation instruments. Table 1 shows example-items of the fully developed test instruments. With regard to the level attractiveness, we use a questionnaire to assess the seminar quality after each thematic block (cf. Schlüter \& Melle, 2018; five-point Likert-scale, 11 items, $\alpha=0.845$ ). In the last seminar session, we use an additional questionnaire on the attractiveness of the methodological design and the given presentations by the lecturer (cf. Schlüter \& Melle, 2018; open questions and five-point Likert-scale with 11 items, $\alpha=0.561$ ). At the level of cognitive changes, we use a translated and adapted version of the TPACK self-efficacy test by Schmidt et al. (cf. Schmidt et al., 2009; five-point Likertscale, 31 items, $\alpha=0.968$ ). Moreover, we designed a test based on the technology acceptance model by Davis to explore the students' attitude towards the use of digital media (cf. Davis et al., 1989; five-point Likert-scale, 34 items, $\alpha=0.910$ ). Additionally, a coding manual is currently being developed to evaluate the extent to which the seminar participation leads to an improvement in the seminar participants' ability to integrate digital tools into their lesson planning based on the growth of their TPACK competencies. Regarding the other evaluations steps however, the final test and evaluation instruments are still in the works but will be carried out within the following months. Therefore, with regard to the evaluation step implementation at school, we will videotape the implemented lesson during the seminar participants' internship semester to subsequently develop a coding manual for analyzing whether the seminar participants are able to adequately implement the seminar contents in school practice with regard to the TPACK model. Lastly, we will use a student questionnaire, which we will hand out after the seminar participants' implemented lessons, to examine the evaluation step effects on the learners. Once the seminar participants have completed their internship semester, we will run the attitude as well as 
the TPACK self-efficacy test as a follow-up test again in order to measure the long-term impact of the seminar on the seminar participants' attitude and TPACK self-efficacy.

Table 1: Example items (cf. Davis et al., 1989; Schlüter \& Melle, 2018; Schmidt et al., 2009).

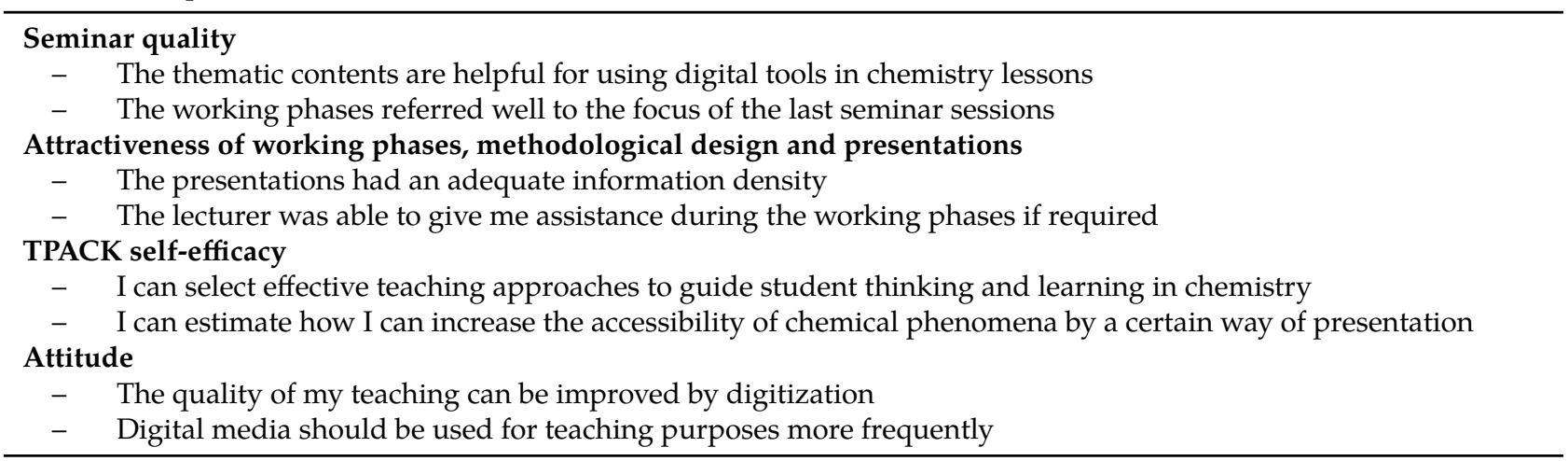

\section{The seminar}

In the seminar "Teaching Methods and Multimedia for Digitization in Chemistry Education", the prospective chemistry teachers learn how to implement digital tools in teaching and learning effectively as well as appropriately. For the successful completion of the seminar, the seminar participants are awarded 3 ECTS credits. Table 2 gives an overview of the main topics of the seminar sessions in the pilot study as well as their corresponding thematic block. In the first sessions, the basics of teaching with digital tools are taught. This is followed by the practical implementation of teaching and learning in chemistry with the aid of digital tools. Within the last thematic block, the future teachers learn methodological basics for teaching chemistry in the digitalized classroom. Consequently, the seminar mainly aims at the development of the seminar participants' competences in the TPACK competence area.

Table 2: Seminar contents and thematic blocks.

\begin{tabular}{|c|c|c|}
\hline Session no. & Content & Thematic block \\
\hline 1. & Introduction and pre tests & \multirow{4}{*}{ I. Basics of teaching with digital tools } \\
\hline 2. & Legal and educational framework & \\
\hline 3. & Organization of teaching in the digital classroom & \\
\hline 4. & $\begin{array}{l}\text { Potentials of digital tools in dealing with } \\
\text { diversity }\end{array}$ & \\
\hline 5. & Multimedia teaching materials I & \multirow{4}{*}{$\begin{array}{l}\text { II. Practical implementation of teaching chem- } \\
\text { istry with digital tools }\end{array}$} \\
\hline 6. & Multimedia teaching materials II & \\
\hline 7. & Multimedia teaching materials III & \\
\hline 8. & Chemical experiments with digital tools & \\
\hline 9. & Gamification and game-based learning & \multirow{5}{*}{ III. Methodological basics } \\
\hline 10. & $\begin{array}{l}\text { Assessment, diagnostics and feedback in the } \\
\text { digital classroom }\end{array}$ & \\
\hline 11. & Pool of ideas and lesson planning & \\
\hline 12. & $\begin{array}{l}\text { Potentials and limitations of multimedia } \\
\text { learning }\end{array}$ & \\
\hline 13. & Post tests & \\
\hline
\end{tabular}

These seminar sessions are methodically designed in such a way that the students first receive new content and information via PowerPoint or video. In order to be able to link this information closely with their future teaching practice, the seminar places a strong focus on the practical implementation of the topics dealt with. Hence, the seminar sessions always include a major working phase in which the students apply new information directly after the input by trying out programs and apps or developing teaching materials themselves. 


\section{Results}

The sample group of the pilot study comprises seven university students who participated in the seminar. Subsequently, the first preliminary results of the pilot study will be presented, following the four evaluation steps by Kirkpatrick (1979). So far, it was only possible to analyze the first two evaluation steps, namely attractiveness and cognitive changes because the seminar participants have just started their internship semester. Since this is a small sample size, the results should be treated carefully.

\section{Attractiveness}

To evaluate the level of attractiveness, the quality of the seminar was assessed three times by the students after block I, II and III (see Table 2).

Based on a descriptive analysis, the results in Figure 5 illustrate that the seminar quality is constantly estimated as very positive by the students. Only the first block was rated minimally less positive with a larger spread. This thematic block is about the general basics of teaching with digital tools.

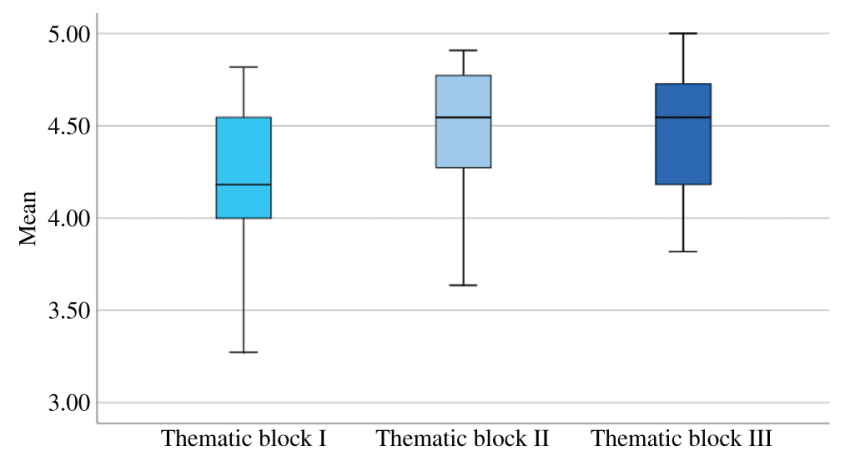

Figure 5: Seminar quality of the four thematic blocks and the aggregated data of all blocks. The descriptive statistics of the seminar quality survey from $1=$ negative to $5=$ positive are shown (block I: $M=4.19, S D=0.54$; block II: $M=4.45, S D$ $=0.44$; block III: $M=4.45, S D=0.41 ; n=7$ ).

Furthermore, a final questionnaire assessing the attractiveness of working phases, the methodological design and the given presentations by the lecturer shows that the students are also very positive about the lecturer $(M=4.80, S D=0.07)$ as well as the working phases and the methodological design of the seminar $(M=4.54$, $S D=0.20)$.

\section{Cognitive changes}

In order to analyze cognitive changes due to the seminar participation, we determine the students' attitude towards using digital tools in teaching and learning, their TPACK self-efficacy perception as well as their ability to integrate digital tools in their lesson plans before (pre) and after (post) the seminar participation.

For this purpose, Figure 6 graphically depicts the results regarding the cognitive changes in the seminar participants' attitude $(p<0.001, \delta=2.60)$ and their self-efficacy perception $(p=0.001, \delta=2.09)$.

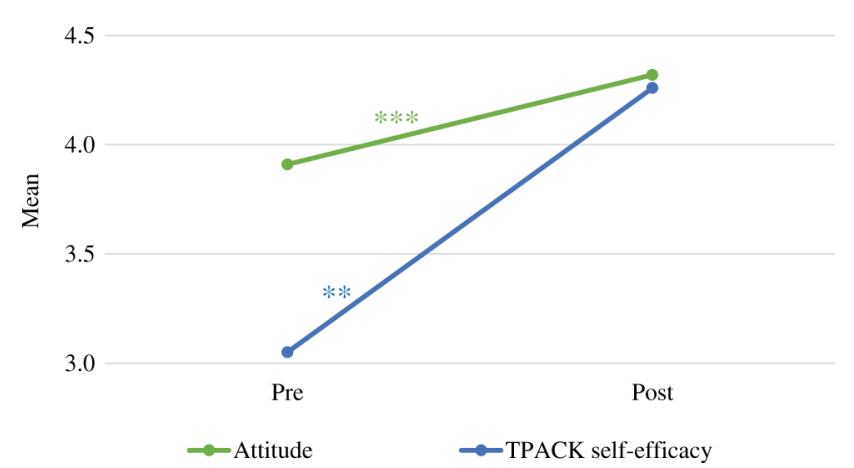

Figure 6: Results regarding the seminar participants attitude and TPACK self-efficacy perception from $1=$ negative to $5=$ positive $(n=7) ;{ }^{* *} p<0.01,{ }^{* * *} p<0.001$. 
The comparison of the pre and post results demonstrates that the prospective teachers' attitudes towards the implementation of digital tools as well as their self-efficacy perception have increased significantly with a big effect-size. However, the implementation of the follow-up test is still pending.

\section{Conclusions and outlook}

Overall, this paper can only present initial responses to the first two research questions so far. Considering the first research question (Q1), the initial results of the pilot study indicate that teacher students assess the seminar as attractive. Moreover, the first results referring to the second research question $(\mathrm{Q} 2 \mathrm{a}+\mathrm{b})$ show that the seminar participation in the university seminar "Teaching Methods and Multimedia for Digitization in Chemistry Education" improves the teacher students' TPACK self-efficacy and attitude towards teaching with digital tools significantly with a big effect size.

However, the evaluation of the other research questions is still in progress. As a second parameter to analyze the cognitive changes, the future teachers' skills in implementing digital tools in their lesson plans are currently being evaluated with a coding manual.

With regards to evaluation step practical implementation, it will be assessed whether the seminar participants are able to adequately implement the seminar contents in their internship semester by accompanying the students during their internship semester and filming their lessons. At the same time and relating to the evaluation step effects on the learners, we will also determine the effects of the lessons planned and carried out by the seminar participants on the learners at school by using a questionnaire. In addition, a follow-up test will be used to analyze the long-term effect of the seminar on the attitude and self-efficacy of the seminar participants.

After the revision of the seminar sessions and test instruments, the main study will begin with the winter semester 2018/19 in which the seminar will be tested with a targeted sample of $N \approx 30$. Additionally, it is planned to compare the results of the main study to a control group to exclude effects that can be attributed to test repetition or the natural development of the students.

To summarize, these first results suggest that the seminar is suitable for professionalizing prospective teachers for digitization in chemistry education as it increases not only the seminar participants' attitude towards digital tools but also their TPACK self-efficacy. Since these findings, in turn, are considered to be highly promising for the actual success of digital learning at school (cf. Figure 2), it will hence be interesting to see the results regarding the change of the seminar participants' ability to integrate digital tools in their lesson plans (Q3). The same applies to the outcomes in the practical implementation of the seminar contents during the internship semester (Q4 and Q5).

Based on the consideration of decisive effects of training programs and the comprehensive analysis of the seminar participants' development in TPACK knowledge on the levels of self-efficacy, lesson planning and practical implementation, this study shall finally provide practical implications for teacher teaching programs. Moreover, the developed and evaluated seminar can also contribute to developing recommendations for the general design and organization of advanced teacher training at the university level.

Nonetheless, there are more courses and seminars necessary than only this one to professionalize future (chemistry) teachers for the competent use of digital tools. This requires the cooperation between all teacher education departments of universities in order to design common concepts and agreements for professionalizing all pre-service teachers for digitization of school education.

\section{Acknowledgments}

I would like to thank the participating future chemistry teachers and the learners as well as the teachers at internship semester schools.

\section{References}

Bang, E., \& Luft, J. A. (2013). Secondary science teachers' use of technology in the classroom during their first 5 years. Journal of Digital Learning in Teacher Education, 29(4), 118-126.

Bastian, J., \& Riplinger, T. (2016). Tablets for a redefinition of learning? An analysis of video observations to determine the integration of tablets in the classroom. In Proceedings of EdMedia 2016 - World Conference on Educational Media and Technology (pp. 143-149). Vancouver, BC, Canada: Association for the Advancement of Computing in Education (AACE). Retrieved December 5, 2018, from https://www.learntechlib.org/primary/p/172944/. 
Becker, S., \& Nerdel, C. (2017). Gelingensbedingungen für die Implementation digitaler Werkzeuge im Unterricht. In J. Meßinger-Koppelt, S. Schanze, \& ]. Groß (Eds.), Lernprozesse mit digitalen Werkzeugen unterstützen - Perspektiven aus der Didaktiknaturwissenschaftlicher Fächer (pp. 36-55). Hamburg: Joachim Herz Stiftung.

Bos, W., Lorenz, R., Endberg, M., Eickelmann, B., Kammerl, R., \& Welling, S. (2016). Schule digital-der Länderindikator 2016. Kompetenzen von Lehrpersonen der Sekundarstufe I im Umgang mit digitalen Medien im Bundesländervergleich. Münster; New York: Waxmann.

Cetin-Dindar, A., Boz, Y., Sonmez, D. Y., \& Celep, N. D. (2018). Development of pre-service chemistry teachers' technological pedagogical content knowledge. Chemistry Education Research and Practice, 19(1), 167-183.

Chai, C. S., Koh, J. H. L. \& Tsai, C. C. (2013). A review of technological pedagogical content knowledge. Journal of Educational Technology \& Society, 16(2), 31-51.

Davis, F. D., Bagozzi, R. P., \& Warshaw, P. R. (1989). User acceptance of computer technology: A comparison of two theoretical models. Management Science, 35(8), 982-1003.

Drossel, K., \& Eickelmann, B. (2017). Teachers' participation in professional development concerning the implementation of new technologies in class - Different types of teachers and their relationship with the use of computers, ICT self-efficacy and emphasis on teaching ICT. Large-scale Assessments in Education, 5(19), 1-13.

European Commission. (2014). The International Computer and Information Literacy Study (ICLS). Main findings and implications for education policies in Europe. Brüssel. Retrieved November 24, 2018, from http://ec.europa.eu/dgs/education_culture/repository/education/library/study/2014/ec-icils_en.pdf.

Fischer, H. E., Borowski, A., \& Tepner, O. (2012). Professional knowledge of science teachers. In B. J. Fraser, K. G. Tobin, \& C. K. McRobbie (Eds.), Second international handbook of science education (pp. 435-448). Dordrecht: Springer.

Gerick, J., \& Eickelmann, B. (2017). Abschlussbericht im Rahmen der wissenschaftlichen Begleitung der Evaluation des Projekts „,Lernen mit digitalen Medien “in Schleswig-Holstein. Retrieved November 24, 2018, from Universität Hamburg/Universität Paderborn. https://www.ew.uni-hamburg.de/ueber-die-fakultaet/personen/gerick/_files/abschlussbericht-evaluation-modellschulen-gerickeickelmann-feb2017.pdf.

Hattie, J. (2008). Visible learning: A synthesis of over 800 meta-analyses relating to achievement. New Work, NY: Routledge.

Hillmayr, D., Reinhold, F., Ziernwald, L., \& Reiss, K. (2017). Digitale Medien im mathematisch-naturwissenschaftlichen Unterricht der Sekundarstufe: Einsatzmöglichkeiten, Umsetzung und Wirksamkeit. Münster: Waxmann.

Instefjord, E. (2015). Appropriation of digital competence in teacher education. Nordic Journal of Digital Literacy, 10, 155-171.

Kirkpatrick, D. L. (1979). Techniques for evaluating training programs. Training and Development Journal, 33(6), 78-92.

KMK. (2016). Strategie der Kultusministerkonferenz "Bildung in der digitalen Welt". Beschluss

der Kultusministerkonferenz vom 08.12.2016. Retrieved November 24, 2018, from

https://www.kmk.org/fileadmin/Dateien/pdf/PresseUndAktuelles/2016/Bildung_digitale_Welt_Webversion.pdf.

Landesregierung NRW. (2016). NRW 4.0: Digitaler Wandel in Nordrhein-Westfalen. Fortschrittsbericht der Landesregierung. Retrieved November 24, 2018, from https://www.land.nrw/sites/default/files/asset/document/digitaler_wandel_in_nrw_fortschrittsbericht_der_landesregierung.pdf.

Mahler, D., \& Arnold, J. (2017) Wissen und Motivation von Lehrkräften in Umgang mit digitalen Technologien. In J. Meßinger-Koppelt, S. Schanze, \& ]. Groß (Eds.), Lernprozesse mit digitalen Werkzeugen unterstützen - Perspektiven aus der Didaktik naturwissenschaftlicher Fächer (pp. 264-277). Hamburg: Joachim Herz Stiftung.

Meyer, A., Rose, D.H., \& Gordon, D. (2014). Universal Design for learning: Theory and practice. Wakefield MA: CAST.

Mishra, P., \& Koehler, M. J. (2006). Technological, pedagogical content knowledge: A framework for teacher knowledge. Teachers College Record, 108(6), 1017-1054.

MPFS Medienpädagogischer Forschungsverbund Südwest. (2017). JIM 2017-Jugend, Information, (Multi-) Media. Basisstudie zum Medienumgang 12-bis 19-Jähriger in Deutschland. Stuttgart. Retrieved November 24, 2018, from https://www.mpfs.de/fileadmin/files/Studien/JIM/2017/JIM_2017.pdf.

Nienaber, A.-K., \& Melle, I. (2018). Professionalization of pre-service chemistry teachers for the competent use of assessment. In O. E. Finlayson, E. McLoughlin, S. Erduran, \& P. Childs (Eds.), Electronic Proceedings of the ESERA 2017 Conference. Research, Practice and Collaboration in Science Education, Part 13 (co-ed. M. Evagorou \& M. Michelini) (pp. 1721-1728). Dublin, Ireland: Dublin City University.

Otterborn, A., Schönborn, K. \& Hultén, M.(2018). Surveying preschool teachers' use of digital tablets: general and technology education related findings. International Journal of Technology and Design Education, 29(4), 717-737.

Paulick, I., Großschedl, J., Harms, U., \& Möller, J. (2016). Preservice teachers' professional knowledge and its relation to academic selfconcept. Journal of Teacher Education, 67(3), 173-182.

Sánchez-Prieto, J. C., Olmos-Migueláñez, S., \& García-Peñalvo, F. J. (2016). Informal tools in formal contexts: Development of a model to assess the acceptance of mobile technologies among teachers. Computers in Human Behavior, 55A, 519-528.

Schlüter, A.-K., \& Melle, I. (2018). Professionalization of future chemistry teachers for teaching in inclusive classrooms. In O. E. Finlayson, E. McLoughlin, S. Erduran, \& P. Childs (Eds.), Electronic Proceedings of the ESERA 2017 Conference. Research, Practice and Collaboration in Science Education, Part 13 (co-ed. M. Evagorou \& M. Michelini) (pp. 1709-1720). Dublin, Ireland: Dublin City University.

Schmid, U., Goertz, L., \& Behrens, J. (2017). Monitor Digitale Bildung: Die Schulen im digitalen Zeitalter. Cütersloh: Bertelsmann Stiftung. Schmidt, D. A., Baran, E., Thompson, A. D., Mishra, P., Koehler, M. J., \& Shin, T. S. (2009). Technological pedagogical content knowledge (TPACK). Journal of Research on Technology in Education, 42(2), 123-149.

Shulman, L. (1986). Those who understand: Knowledge growth in teaching. Educational Researcher, 15(2), 4-14. 